\title{
Prawo właściwe dla czynności prawnych związanych z zarządem sukcesyjnym
}

\begin{abstract}
The Act of 5 July 2018 on the succession administration of the business of a physical person introduced a possibility to carry out transactions relating to establishing and performing administration of the estate. In particular, the Act permits to appoint a succession administrator and empowers him or her to carry out legal transactions relating to the business of the deceased entrepreneur. A need to determine the law applicable to these legal transactions arises. The article contains an analysis of the conflict rules adopted in the EU Succession Regulation. From this analysis the author draws a conclusion that the appointment of the succession administrator and the legal acts relating thereto are subject to the law applicable to succession. Likewise one should classify legal transactions relating to the administration of the business undertaken by persons named in the Act to carry out administration in the period before the succession administration is established. The prerequisites of the validity of the legal transactions carried out by the effectively nominated succession administrator on the other hand are subject to the law applicable to the given legal transactions, as according to general rules relating thereto. This includes, inter alia, that the legal acts falling with the scope of the law applicable to succession (Article 23 of the Succession Regulation), are governed by that law.
\end{abstract}

Keywords: succession administration, the law applicable to succession, business, succession administrator, conservatory acts

a) Prof. dr hab., Uniwersytet Ślaski w Katowicach. 


\section{Uwagi wprowadzające}

Dnia 25 listopada 2018 r. weszła w życie ustawa z dnia 5 lipca 2018 r. o zarządzie sukcesyjnym przedsiębiorstwem osoby fizycznej ${ }^{1}$. Zgodnie $\mathrm{z}$ jej art. 1, reguluje ona zasady tymczasowego zarządzania przedsiębiorstwem po śmierci przedsiębiorcy, który we własnym imieniu wykonywał działalność gospodarczą na podstawie wpisu do Centralnej Ewidencji i Informacji o Działalności Gospodarczej [dalej: CEIDG]², oraz kontynuowania działalności gospodarczej wykonywanej $\mathrm{z}$ wykorzystaniem tego przedsiębiorstwa, zwanego $\mathrm{w}$ dalszych przepisach ustawy przedsiębiorstwem w spadku ${ }^{3}$.

Realizacja celu ustawy wymaga dokonania szeregu czynności prawnych, z których najistotniejsze znaczenie ma powołanie zarządcy sukcesyjnego. Może ono nastąpić albo za życia przedsiębiorcy, albo po jego śmierci. W tym pierwszym przypadku przedsiębiorca na podstawie art. 9 ust. 1 ustawy powołuje zarządcę sukcesyjnego w ten sposób, że wskazuje określoną osobę do pełnienia funkcji zarządcy sukcesyjnego albo zastrzega, że z chwila jego śmierci wskazany prokurent stanie się zarządcą sukcesyjnym. Do ustanowienia zarządcy potrzeba wówczas

${ }^{1}$ Dz.U. poz. 1629. Od 1 stycznia 2020 r. - ustawa o zarządzie sukcesyjnym przedsiębiorstwem osoby fizycznej i innych ułatwieniach związanych z sukcesją przedsiębiorstw (zob. art. 66 pkt 1 i art. 86 ustawy z dnia 31 lipca 2019 r. o zmianie niektórych ustaw w celu ograniczenia obciążeń regulacyjnych. Dz.U. poz. 1495) [dalej: ustawa]. Szerzej na temat zarządu sukcesyjnego zob. T. Szczurowski: Zarzad sukcesyjny przedsiębiorstwem w spadku. „Przegląd Ustawodawstwa Gospodarczego” 2018, nr 11, s. 31 i n.; J. Bieluk: Ustawa o zarzqdzie sukcesyjnym przedsiębiorstwem osoby fizycznej. Komentarz. Warszawa 2019, passim; R. Blicharz: Zarzqd sukcesyjny przedsiębiorstwem $w$ spadku. Warszawa 2019, passim. Pozycję prawną zarządcy sukcesyjnego omawiaja: M. Pazdan: Zarzadca sukcesyjny a wykonawca testamentu. W: „Ius est ars boni et aequi". Księga pamiatkowa dedykowana Profesorowi Józefowi Frqckowiakowi. Red. A. Dańko-Roesler, M. Leśniak, M. Skory, B. Sołtys. Wrocław 2018, s. 885 i n.; K. Kopaczyńska-Pieczniak: Status prawny zarzadcy sukcesyjnego. „Przegląd Prawa Handlowego" 2018, nr 12, s. 4 i n.; K. Kopystyński: Zarzadca sukcesyjny jako przedsiębiorca. „Przegląd Ustawodawstwa Gospodarczego” 2019, nr 6, s. 18 i n.; P. Pacek: Wykonawca testamentu a zarzad sukcesyjny przedsiębiorstwem osoby fizycznej-wybrane zagadnienia. „Rejent” 2019, nr 6, s. 59 i n.; R. Kapkowski, M. Kaufmann: Charakter prawny zarzadcy sukcesyjnego na tle pokrewnych instytucji zarzadu masq spadkowa. „Rejent” 2019, nr 7, s. 54 i n.

${ }^{2}$ Zob. też ustawę o Centralnej Ewidencji i Informacji o Działalności Gospodarczej i Punkcie Informacji dla Przedsiębiorcy z dnia 6 marca 2018 r. T.j. Dz.U. 2019, poz. 1291.

${ }^{3}$ Zob. art. 2 ustawy. W przypadkach, o których mowa w rozdziale 8 ustawy, jej przepisy odnoszące się do przedsiębiorstwa w spadku stosuje się też odpowiednio do udziału przedsiębiorcy w majątku wspólnym wspólników spółki cywilnej. 
jeszcze zgody osoby wskazanej jako zarządca oraz wpisu zarządcy sukcesyjnego do CEIDG.

Powołanie zarządcy sukcesyjnego przez przedsiębiorcę oraz wyrażenie zgody osoby powołanej na zarządcę sukcesyjnego na pełnienie tej funkcji wymagają zachowania formy pisemnej pod rygorem nieważności.

$\mathrm{Na}$ zarządcę sukcesyjnego może być powołana tylko osoba fizyczna, która ma pełną zdolność do czynności prawnych. Nie może pełnić funkcji zarządcy sukcesyjnego osoba, wobec której prawomocnie orzeczono: zakaz prowadzenia działalności gospodarczej, o którym mowa w art. 373 ust. 1 ustawy Prawo upadłościowe ${ }^{4}$, lub środek karny albo środek zabezpieczajacy w postaci zakazu prowadzenia określonej działalności gospodarczej, obejmujący działalność gospodarczą wykonywana przez przedsiębiorcę lub działalność gospodarczą w zakresie zarządu majątkiem. Funkcję zarządcy sukcesyjnego w danym czasie może pełnić tylko jedna osoba, i to nawet wówczas, gdy zmarły przedsiębiorca prowadził kilka przedsiębiorstw.

Jeżeli zarząd sukcesyjny nie został skutecznie ustanowiony za życia przez przedsiębiorcę, to po jego śmierci zarządcę sukcesyjnego może powołać: małżonek przedsiębiorcy, któremu przysługuje udział w przedsiębiorstwie w spadku, lub spadkobierca ustawowy przedsiębiorcy, który przyjął spadek, albo spadkobierca testamentowy przedsiębiorcy, który przyjął spadek, albo zapisobierca windykacyjny, który przyją zapis windykacyjny, jeżeli zgodnie z ogłoszonym testamentem przysługuje mu udział w przedsiębiorstwie w spadku.

Jeżeli nie zostało wydane prawomocne postanowienie o stwierdzeniu nabycia spadku, nie został zarejestrowany akt poświadczenia dziedziczenia ani nie zostało wydane europejskie poświadczenie spadkowe, wielkość udziałów w przedsiębiorstwie $\mathrm{w}$ spadku ustala się z uwzględnieniem wszystkich znanych osobie powołującej zarządcę sukcesyjnego osób, którym w chwili powołania zarządcy sukcesyjnego przysługuje udział w przedsiębiorstwie $\mathrm{w}$ spadku.

Po uprawomocnieniu się postanowienia o stwierdzeniu nabycia spad$\mathrm{ku}$, zarejestrowaniu aktu poświadczenia dziedziczenia albo wydaniu europejskiego poświadczenia spadkowego zarządcę sukcesyjnego może powołać wyłącznie właściciel przedsiębiorstwa w spadku. Właścicielem przedsiębiorstwa w spadku w rozumieniu ustawy jest:

a) osoba, która zgodnie z prawomocnym postanowieniem o stwierdzeniu nabycia spadku, zarejestrowanym aktem poświadczenia dziedziczenia albo europejskim poświadczeniem spadkowym, nabyła składniki przedsiębiorstwa zmarłego przedsiębiorcy na podstawie powołania do

${ }^{4}$ Ustawa z dnia 28 lutego 2003 r. T.j. Dz.U. 2019, poz. 498 ze zm. 
spadku z ustawy albo testamentu ${ }^{5}$, albo nabyła przedsiębiorstwo albo udział $\mathrm{w}$ przedsiębiorstwie na podstawie zapisu windykacyjnego ${ }^{6}$;

b) małżonek przedsiębiorcy, któremu przysługuje udział w przedsiębiorstwie w spadku;

c) osoba, która nabyła przedsiębiorstwo w spadku albo udział w przedsiębiorstwie w spadku bezpośrednio od osoby, o której mowa powyżej, w tym osoba prawna albo jednostka organizacyjna, o której mowa w art. $33^{1} \S 1$ k.c., do której wniesiono przedsiębiorstwo tytułem wkła$\mathrm{du}-\mathrm{w}$ przypadku, gdy po śmierci przedsiębiorcy nastąiło zbycie tego przedsiębiorstwa albo udziału w tym przedsiębiorstwie.

Wielkość udziałów w przedsiębiorstwie w spadku ustala się według wielkości udziałów spadkowych lub udziałów we współwłasności przedsiębiorstwa. Do powołania zarządcy sukcesyjnego po śmierci przedsiębiorcy wymagana jest zgoda osób, którym łącznie przysługuje udział w przedsiębiorstwie w spadku większy niż 85/100.

Osoba powołująca zarządcę sukcesyjnego po śmierci przedsiębiorcy składa przed notariuszem oświadczenie o przysługujacym jej udziale w przedsiębiorstwie w spadku oraz o znanych jej innych osobach, którym przysługuje udział w przedsiębiorstwie w spadku. Do powołania zarządcy sukcesyjnego wystarczy wtedy oświadczenie jednej z uprawnionych osób oraz zgoda pozostałych.

Powołanie zarządcy sukcesyjnego po śmierci przedsiębiorcy oraz zgoda na jego powołanie wymagają zachowania formy aktu notarialnego.

Powołanie zarządcy sukcesyjnego po śmierci przedsiębiorcy notariusz zobowiązany jest niezwłocznie zgłosić do CEIDG. Powinien to uczynić nie później jednak niż w następnym dniu roboczym po dniu powołania zarządcy sukcesyjnego. Zarządca sukcesyjny powołany po śmierci przedsiębiorcy pełni funkcję od chwili dokonania wpisu do CEIDG tego zarządcy, natomiast ten powołany za życia przedsiębiorcy — od chwili śmierci przedsiębiorcy (art. 7 ust. 1 ustawy). Od tej chwili zarządca sukcesyjny wykonuje prawa i obowiązki zmarłego przedsiębiorcy wynikające $\mathrm{z}$ wykonywanej przez niego działalności gospodarczej oraz prawa i obowiązki

${ }^{5}$ Ustawa pomija nieznane polskiemu prawu tytuły dziedziczenia. Nie można jednak wykluczać, że następstwo prawne po zmarłym przedsiębiorcy opierać się będzie np. na znanej niektórym ustawodawstwom umowie dziedziczenia. Stanie się tak wówczas, gdy prawem właściwym dla spraw spadkowych po zmarłym przedsiębiorcy jest prawo obce. Zob. także M. Pazdan: O umowach dziedziczenia zawieranych przed polskimi notariuszami. „Rejent” 1996, nr 4-5, s. 60 i n.

${ }^{6}$ Według ustawy, w przypadku zapisu windykacyjnego przedsiębiorstwa na rzecz jednego zapisobiercy oraz dziedziczenia przez jednego spadkobiercę można stosować zarząd sukcesyjny tylko do czasu uprawomocnienia się postanowienia sądu stwierdzającego nabycie spadku (zarejestrowania aktu poświadczenia dziedziczenia, wydania europejskiego poświadczenia spadkowego) - zob. art. 59 ust. 1 pkt 2 ustawy. 
wynikajace z prowadzenia przedsiębiorstwa w spadku (art. 29 ustawy). Zarządca sukcesyjny działa w imieniu własnym, na rachunek właściciela przedsiębiorstwa w spadku (art. 21 ust. 1 ustawy).

Uprawnienie do powołania zarządcy sukcesyjnego wygasa z upływem dwóch miesięcy od dnia śmierci przedsiębiorcy. Jeżeli akt zgonu przedsiębiorcy nie zawiera daty zgonu albo chwila śmierci przedsiębiorcy została oznaczona w postanowieniu stwierdzającym zgon, termin ten biegnie od dnia znalezienia zwłok przedsiębiorcy albo uprawomocnienia się postanowienia stwierdzającego zgon (art. 12 ust. 10 ustawy).

Celem niniejszego opracowania jest ustalenie, jakiemu prawu należy poddać wskazane powyżej czynności prawne związane z powołaniem zarządcy sukcesyjnego (pkt 3), a ponadto czynności prawne dokonywane przez zarządcę sukcesyjnego (pkt 4) oraz tzw. czynności zachowawcze podejmowane jeszcze przed ustanowieniem zarządu sukcesyjnego (pkt 5). Przy dokonywaniu tych czynności prawnych pojawić się może bowiem tzw. element obcy (zagraniczny) ${ }^{7}$ i wówczas niezbędne stanie się dokonanie takiego ustalenia. Aby wskazany cel zrealizować, konieczne jest jednak uprzednie omówienie zagadnień związanych z ustalaniem prawa właściwego dla spraw spadkowych (statutu spadkowego) oraz określenie zakresu jego zastosowania (pkt 2).

\section{Prawo właściwe dla ogółu spraw spadkowych}

Aspekty kolizyjnoprawne związane z dziedziczeniem uregulowane sa obecnie w rozporządzeniu spadkowym ${ }^{8}$. Prawo właściwe dla ogółu spraw spadkowych wskazuja przede wszystkim art. 21 i 22 rozporządzenia spadkowego ${ }^{9}$. Według art. 21 rozporządzenia, co do zasady prawem właś-

${ }^{7}$ Zob. M. Pazdan: Prawo prywatne międzynarodowe. Warszawa 2017, s. 23 i n.

${ }^{8}$ Rozporządzenie Parlamentu Europejskiego i Rady (UE) nr 650/2012 z dnia 4 lipca 2012 r. w sprawie jurysdykcji, prawa właściwego, uznawania i wykonywania orzeczeń, przyjmowania i wykonywania dokumentów urzędowych dotyczących dziedziczenia oraz w sprawie ustanowienia europejskiego poświadczenia spadkowego. Dz.Urz. UE L 201, s. 107 [dalej: rozporządzenie spadkowe].

${ }^{9}$ Zob.: C. Fischer-Czermak: Anwendbares Recht. In: Europäische Erbrechtsverordnung. Hrsg. M. Schauer, E. Scheuba. Wien 2012, s. 43 i n.; A. Wieczorek: Ustalenie prawa wtaściwego w świetle rozporzqdzenia spadkowego nr 650/2012. „Problemy Prawa Prywatnego Międzynarodowego" 2017, T. 21, s. 74 i n.; M. Pazdan, w: Prawo prywatne międzynarodowe. Komentarz. Red. M. Pazdan. Warszawa 2018, s. 1162 i n. oraz dalszą powołaną tam literaturę. 
ciwym dla ogółu spraw dotyczących spadku jest prawo państwa, w którym zmarły miał miejsce zwykłego pobytu w chwili śmierci. W przypadku, gdy wyjątkowo ze wszystkich okoliczności sprawy jasno wynika, że $\mathrm{w}$ chwili śmierci zmarły był w sposób oczywisty bliżej związany z państwem innym niż państwo ostatniego miejsca jego zwykłego pobytu, prawem właściwym dla dziedziczenia jest prawo tego innego państwa. Jednak zgodnie z art. 22 rozporządzenia spadkowego, każdy może dokonać wyboru prawa państwa, którego jest obywatelem w chwili dokonywania wyboru lub w chwili śmierci, jako prawa, któremu podlega ogół spraw dotyczacych jego spadku. Kto jest obywatelem więcej niż jednego państwa może wybrać prawo każdego państwa, którego jest obywatelem w chwili dokonywania wyboru lub w chwili śmierci. Wybór prawa musi być dokonany w sposób wyraźny w oświadczeniu złożonym w formie wymaganej dla rozrządzenia na wypadek śmierci lub musi wynikać z postanowień takiego rozrządzenia.

W związku z powyższym prawo polskie znajdzie zastosowanie do spraw spadkowych po zmarłym przedsiębiorcy prowadzacym w Polsce działalność gospodarczą ujawnioną w CEIDG, jeżeli:

a) dokonał on na podstawie art. 22 rozporządzenia spadkowego skutecznego wyboru polskiego prawa jako właściwego dla ogółu spraw dotyczacych jego spadku;

b) w braku wyboru prawa (jego nieskuteczności) miał on w chwili śmierci miejsce zwykłego pobytu w Polsce albo

c) w chwili śmierci przedsiębiorca był w sposób oczywisty bliżej związany z Polska, mimo że nie była ona państwem miejsca jego zwykłego pobytu w chwili śmierci; za takim bliskim związkiem może przemawiać np. fakt prowadzenia działalności gospodarczej w Polsce.

Obce prawo znajdzie zastosowanie jako statut spadkowy wówczas, gdy przedsiębiorca prowadzacy w Polsce przedsiębiorstwo:

a) dokonał skutecznie wyboru obcego prawa ojczystego jako statutu spadkowego (także wtedy, gdy był jednocześnie również obywatelem polskim lub w chwili śmierci jego miejsce zwykłego pobytu znajdowało się w Polsce);

b) w razie braku wyboru prawa (jego nieskuteczności) miał on w chwili śmierci miejsce zwykłego pobytu poza granicami Polski albo

c) w chwili śmierci był w sposób oczywisty bliżej związany z państwem innym niż Polska, która była państwem miejsca jego zwykłego pobytu w chwili śmierci.

To ostatnie jest jednak mało prawdopodobne ze względu na to, że przedsiębiorstwo zmarłego przedsiębiorcy znajduje się w Polsce. Nie można jednak wykluczyć, że przedsiębiorca prowadził także przedsiębiorstwo/przedsiębiorstwa położone w innym państwie, choć miejsce jego 
zwykłego pobytu w chwili śmierci znajdowało się w Polsce. Wówczas można wykazywać bliższy związek zmarłego przedsiębiorcy z tym innym państwem, a tym samym doprowadzić do zastosowania prawa tego państwa jako statutu spadkowego.

Według art. 23 rozporządzenia spadkowego, statutowi spadkowemu podlegają w szczególności:

a) przyczyny, czas i miejsce otwarcia spadku;

b) określenie beneficjentów, ich udziałów i obowiąków, które mógł nałożyć na nich zmarły, oraz ustalenie innych praw spadkowych, w tym praw spadkowych pozostającego przy życiu małżonka lub partnera;

c) zdolność do dziedziczenia;

d) wydziedziczenie i niegodność dziedziczenia;

e) przejście składników majątku, praw i obowiązków wchodzących w skład spadku na spadkobierców oraz, w stosownych przypadkach, na zapisobierców, w tym warunki i skutki przyjęcia lub odrzucenia spadku lub zapisu;

f) uprawnienia spadkobierców, wykonawców testamentów i innych zarządców spadku, w szczególności dotyczące sprzedaży składników majatku i zaspokojenia wierzycieli, bez uszczerbku dla uprawnień, o których mowa w art. 29 ust. 2 i 3 rozporzadzenia spadkowego ${ }^{10}$;

g) odpowiedzialność za długi spadkowe;

h) rozrządzalna część spadku, udziały obowiąkowe oraz inne ograniczenia w rozrządzaniu na wypadek śmierci, oraz roszczenia, jakie osoby bliskie zmarłego moga zgłaszać wobec majątku spadkowego lub spadkobierców;

i) obowiazek zwrotu lub zaliczenia darowizn i zapisów przy określaniu udziałów należnych różnym beneficjentom;

j) dział spadku'11.

Poza zakresem zastosowania statutu spadkowego znajduje się m.in. dziedziczność przedsiębiorstwa (a właściwie jego składników). Podlega ona prawu właściwemu dla poszczególnych składników przedsiębiorstwa $^{12}$. W przypadku przedsiębiorstwa, którego materialne składniki

${ }^{10}$ Artykuł 29 rozporządzenia spadkowego dotyczy zasadniczo zarządców, których powołanie przez sąd jest obligatoryjne. Wyraźnie poddaje się ich działanie statutowi spadkowemu. Zob. Ł. Żarnowiec: Wptyw statutu rzeczowego na rozstrzyganie spraw spadkowych - na styku statutów. Warszawa 2018, s. 232 i n.; zob. też M. Pazdan: Zarzad sukcesyjny-aspekty kolizyjnoprawne. W: Prawo handlowe. Między teoria, praktyka a orzecznictwem. Księga jubileuszowa dedykowana Profesorowi Januszowi A. Strzępce. Red. P. Pinior i in. Warszawa 2019, s. 72.

${ }^{11}$ Szerzej na temat zakresu zastosowania statutu spadkowego zob. M. Pazdan, w: Prawo prywatne międzynarodowe. Komentarz. Red. M. Pazdan..., s. 1180 i n.

${ }^{12} \mathrm{~W}$ kwestii kolizyjnoprawnej kwalifikacji przedsiębiorstwa zob. C. Wendehorst, in: Münchener Kommentar. Bd. 11. Internationales Privatrecht II. Hrsg. J. von Hein. 
(rzeczy) położone są w kilku państwach, o ich dziedziczności rozstrzygać należy przede wszystkim na podstawie prawa państwa miejsca ich położenia (art. 41 ustawy Prawo prywatne międzynarodowe) ${ }^{13}$.

Dziedziczność prawa do udziału w majątku wspólnym wspólników spółki cywilnej podlega prawu właściwemu dla tej spółki (zob. art. 21 w zw. z art. 17 p.p.m. 2011). Artykuł 1 ust. 2 lit. h rozporządzenia spadkowego wyraźnie wyłącza z zakresu stosowania rozporządzenia spadkowego kwestie dotyczace spółek i innych podmiotów posiadajacych osobowość prawną lub jej nieposiadających, takie jak postanowienia aktów założycielskich i statutów spółek i innych podmiotów posiadających osobowość prawną lub jej nieposiadających, które określają los udziałów po śmierci członków ${ }^{14}$.

Ponadto ustalenie wynikającego z ustroju majątkowego udziału małżonka w przedsiębiorstwie w spadku należy do kompetencji statutu stosunków majątkowych małżeńskich. Zgodnie bowiem z art. 1 ust. 2 lit. d rozporządzenia spadkowego, także kwestie związane $\mathrm{z}$ małżeńskimi ustrojami majątkowymi sa wyłączone z zakresu zastosowania tego rozporządzenia. Zatem o tym, czy przedsiębiorstwo w spadku należało do majątku osobistego zmarłego przedsiębiorcy, czy też wchodziło w skład majątku wspólnego przedsiębiorcy i jego małżonka decyduje prawo właściwe ustalone na podstawie art. 51 i 52 p.p.m. $2011^{15}$.

\section{Prawo właściwe dla powołania zarządey sukcesyjnego}

Podstawową kwestią, jaka pojawia się przy kolizyjnoprawnej analizie instytucji zarządu sukcesyjnego, jest przesądzenie o tym, któremu prawu podlega powołanie zarządcy sukcesyjnego oraz wykonywanie przez niego zarządu sukcesyjnego. Jak wskazano powyżej, według art. 23 lit. f

München 2015, s. 195; H.P. Mansel, in: Staudinger BGB. Art. 43-46 EGBGB. Internationales Sachenrecht. Hrsg. D. Henrich. Berlin 2015, s. 259 i n. Zob. także uchwałę SN z dnia 25 czerwca 2008 r., III CZP 45/08. „Orzecznictwo Sądu Najwyższego - Izba Cywilna” 2009, nr 7-8, poz. 97; wyr. SN z dnia 31 marca 2015 r., II CSK 427/14. Legalis; wyr. SN z dnia 18 kwietnia 2019 r., II CSK 197/18. Legalis.

${ }^{13}$ Ustawa z dnia 4 lutego 2011 r. T.j. Dz.U. 2015, poz. 1792 [dalej: p.p.m. 2011]. Zob. jednak także art. 42 i 43 p.p.m. 2011 oraz J. Górecki, w: Prawo prywatne międzynarodowe. Komentarz. Red. M. Pazdan..., s. 374 i n.

${ }^{14}$ Zob. np. art. 872 k.c.

15 Szerzej zob. P. Twardoch, w: Prawo prywatne międzynarodowe. Komentarz. Red. M. Pazdan..., s. 459 i n. 
rozporządzenia spadkowego, uprawnienia spadkobierców, wykonawców testamentów i innych zarządców spadku, w szczególności dotyczące sprzedaży składników majątku i zaspokojenia wierzycieli, podlegają statutowi spadkowemu. Oznaczałoby to, że przepisy ustawy regulujące zarząd przedsiębiorstwem w spadku można stosować jedynie wtedy, gdy dziedziczenie po zmarłym przedsiębiorcy podlega prawu polskiemu. Natomiast jeśli statutem spadkowym jest prawo obce, ustanowienie zarządu sukcesyjnego i jego wykonywanie może być oparte tylko na tym obcym prawie.

Przed ostatecznym rozstrzygnięciem wskazanej powyżej kwestii należy jeszcze rozważyć, czy do innych wniosków nie doprowadzi zastosowanie art. 30 rozporządzenia spadkowego ${ }^{16}$. Stanowi on bowiem, że w przypadku, gdy prawo państwa, w którym znajdują się niektóre nieruchomości, niektóre przedsiębiorstwa lub inne szczególne kategorie składników majątku, zawiera szczególne przepisy nakładające z przyczyn ekonomicznych, rodzinnych lub społecznych ograniczenia dotyczace dziedziczenia lub wpływające na dziedziczenie w odniesieniu do tych składników majątku, te szczególne przepisy mają zastosowanie do dziedziczenia w takim zakresie, w jakim na mocy prawa tego państwa maja one zastosowanie bez względu na prawo właściwe dla dziedziczenia.

Artykuł 30 rozporządzenia spadkowego przełamuje przyjmowana $\mathrm{w}$ tym rozporządzeniu zasadę jednolitości statutu spadkowego ${ }^{17}$. Ma on charakter wyjątkowy, dlatego wymaga ścisłej wykładni ${ }^{18}$. Potwierdza to

${ }^{16}$ Szerzej na temat art. 30 rozporządzenia spadkowego zob. G. Contaldi, in: The EU Succession Regulation. A Commentary. Eds. A.L. Calvo Caravaca, A. Davi, H.-P. Mansel. Cambridge 2016, s. 430 i n.; M.A. Zachariasiewicz, w: Prawo prywatne międzynarodowe. Komentarz. Red. M. Pazdan..., s. 1225 i n.; Ł. Żarnowiec: Wptyw statutu..., s. 304 i n.; A. Machnikowska, w: Unijne rozporzqdzenie spadkowe nr 650/2012. Komentarz. Red. M. Załucki. Warszawa 2018, s. 233 i n.; M. Margoński, w: „Komentarze Prawa Prywatnego”. T. 4 B: Prawo i postępowanie spadkowe. Red. K. Osajda. Warszawa 2018, s. 67 i n.; Ł. Żar nowiec: Wptyw przepisów wymuszajacych swoje zastosowanie na rozstrzyganie spraw spadkowych pod rzqdami rozporzadzenia Parlamentu Europejskiego i Rady (UE) nr 650/2012. „Problemy Prawa Prywatnego Międzynarodowego" 2019, T. 25, s. 47 i n.; A. Köhler, in: Internationales Erbrecht. Hrsg. W. Gierl, A. Köhler, L. KroiB, H. Wilsch. Baden-Baden 2020, s. 88 i n.

${ }_{17}$ Zob. S. Nietner: Internationaler Entscheidungseinklang im europäischen Kollisionsrecht. Tübingen 2016, s. 125-126, s. 306 i n.; K.A. Dadańska: O realizacji zasady jednolitości statutu spadkowego w świetle rozporzqdzenia nr 650/2012. „Problemy Prawa Prywatnego Międzynarodowego" 2016, T. 19, s. 75 i n.; A. Köhler, in: Internationales Erbrecht. Hrsg. W. Gierl, A. Köhler, L. KroiB, H. Wilsch..., s. 88; A. Machnikowska, w: Unijne rozporzadzenie..., s. 236; M. Margoński, w: „Komentarze Prawa Prywatnego". T. 4 B..., s. 68. Zob. także post. SN z dnia 11 marca 2016 r., I CSK 64/15. Legalis.

18 Zob. orzeczenie OLG Nürnberg z dnia 27 października 2017 r., 15 W 1461/17. „Zeitschrift für Erbrecht und Vermögensnachfolge" 2018, s. 339 oraz D. Looschelders, in: Nomoskommentar. Bd. 6. Rom-Verordnungen. Hrsg. R. Hüstege, H.P. Mansel. Ba- 
także uwaga 54 preambuły rozporządzenia spadkowego, w której wprawdzie zaznaczono, że ze względów ekonomicznych, rodzinnych lub społecznych niektóre nieruchomości, przedsiębiorstwa i inne szczególne kategorie składników majątku podlegać mogą szczególnym uregulowaniom w państwie członkowskim, w którym się znajdują, nakładającym ograniczenia dotyczące dziedziczenia tych składników majątku lub wpływające na ich dziedziczenie, dlatego w rozporządzeniu spadkowym należy zapewnić stosowanie tych szczególnych uregulowań. Ze względu jednak na konieczność zachowania zgodności z ogólnym celem rozporządzenia (tzn. jednolitościa statutu spadkowego) ten wyjatek od stosowania prawa właściwego dla dziedziczenia należy interpretować ściśle ${ }^{19}$.

Zastosowanie art. 30 rozporządzenia spadkowego w odniesieniu do dziedziczenia przedsiębiorstw zależy od kumulatywnego spełnienia następujących przesłanek ${ }^{20}$ :

a) przedsiębiorstwo położone jest w innym państwie niż państwo, którego prawo wskazane jest jako statut spadkowy; nie ma przy tym znaczenia, czy statut spadkowy wyznaczony jest poprzez wybór prawa, czy też z wykorzystaniem łączników obiektywnych;

b) prawo tego innego państwa zawiera szczególne przepisy nakładające z przyczyn ekonomicznych, rodzinnych lub społecznych ograniczenia dotyczące dziedziczenia lub wpływające na dziedziczenie przedsiębiorstwa;

c) na mocy prawa tego innego państwa szczególne przepisy mają zastosowanie do dziedziczenia przedsiębiorstwa bez względu na prawo właściwe dla dziedziczenia.

Nie jest natomiast konieczne, aby przedsiębiorstwo wyczerpywało spadek lub stanowiło choćby jego przeważająca część.

Ustalenie miejsca położenia przedsiębiorstwa w rozpatrywanym przypadku nie powinno nastręczać większych trudności. Z faktu reje-

den-Baden 2015, s. 954; M.A. Zachariasiewicz: Przepisy wymuszajace swoje zastosowanie a statut spadkowy. W: Nowe europejskie prawo spadkowe. Red. M. Pazdan, J. Górecki. Warszawa 2015, s. 330.

${ }^{19}$ W literaturze jako najbardziej oczywisty przykład zastosowania art. 30 rozporządzenia spadkowego wskazuje się przepisy dotyczące szczególnych zasad dziedziczenia gospodarstw rolnych. Zob. J. Müller-Lukoschek: Die neue EU-Erbrechtsverordnung. Bonn 2013, s. 86; M. Mataczy ń ski: Przepisy ograniczajace dziedziczenie na tle art. 30 rozporzadzenia spadkowego. W: Nowe europejskie prawo spadkowe. Red. M. Pazdan, J. Górecki..., s. 301 i n.; M.A. Zachariasiewicz: Przepisy wymuszajace..., s. 323; G. Contaldi, in: The EU Succession..., s. 432 i n. Zob. także M. Pazdan: Zarzqd sukcesyjny..., s. 74 .

${ }_{20}$ Zob. A. Dutta, in: Münchener Kommentar. Bd. 10. Internationales Privatrecht I. Hrsg. J. von Hein. München 2015, s. 1570; A. Köhler, in: Internationales Erbrecht. Hrsg. W. Gierl, A. Köhler, L. KroiB, H. Wilsch..., s. 89 i n. 
stracji przedsiębiorcy w CEIDG pośrednio wynika bowiem, że prowadzi on swoje przedsiębiorstwo $\mathrm{w}$ Polsce. $\mathrm{Z}$ tego też względu przyjąć należy, że rejestracja w CEIDG przesądza, że zmarły przedsiębiorca prowadził swoje przedsiębiorstwo położone w Polsce. Nie jest jednak wykluczone, że niektóre składniki tego przedsiębiorstwa znajdują się poza granicami Polski. Będa to przede wszystkim rzeczy ruchome (np.: ciągniki siodłowe, maszyny, towary, surowce do produkcji), ale moga to być także nieruchomości oraz prawa do nieruchomości.

Zgodnie z art. 3 ust. 1 lit. a rozporządzenia spadkowego, „dziedziczenie" oznacza dziedziczenie majątku po osobie zmarłej i obejmuje wszystkie formy przejścia składników majątku, praw i obowiązków na skutek śmierci, czy to na podstawie dobrowolnego rozrządzenia na wypadek śmierci, czy to w drodze dziedziczenia ustawowego. Dziedziczenie jest zatem rozumiane jedynie jako następstwo prawne po zmarłej osobie fizycznej. Natomiast pojęcie to nie obejmuje swoim zakresem losu majątku zmarłej osoby fizycznej po przejściu tego majątku na jej następców prawnych z mocy ustawy albo rozrządzenia mortis causa.

Przepisy, o których mowa w art. 30 rozporządzenia spadkowego, maja nakładać z przyczyn ekonomicznych, rodzinnych lub społecznych ograniczenia dotyczace dziedziczenia lub wpływać na dziedziczenie przedsiębiorstwa. Nie jest jednak jasne, o jakie przepisy dokładnie chodzi ${ }^{21}$. Znaczna część przepisów prawa spadkowego jest bowiem motywowana względami rodzinnymi, społecznymi i ekonomicznymi. Poza tym przepisy prawa spadkowego dotyczace dziedziczenia ustawowego ze swej natury ograniczają dziedziczenie po zmarłym, gdyż eliminują z tego dziedziczenia część osób bliskich zmarłego, przyznając prawa spadkowe tylko wskazanym osobom, których krąg jest ograniczony. Można się jedynie domyślać, że chodzi tu o przepisy, które dla określonych w art. 30 rozporządzenia spadkowego przedmiotów przewiduja szczególne zasady dziedziczenia (następstwa prawnego) ${ }^{22}$. Dotyczyć one mogą zarówno sposobu ich nabycia przez następców prawnych, jak i wyłączenia oznaczonych osób od dziedziczenia tych składników albo stawiania ich nabywcom dodatkowych wymagań ${ }^{23}$.

Wreszcie dla zastosowania regulacji $\mathrm{z}$ art. 30 rozporzązenia spadkowego wymagane jest, aby szczególne przepisy, które ograniczają dziedziczenie lub wpływają na nie, znajdowały zastosowanie bez względu

${ }^{21}$ Zob. M. Mataczyński: Przepisy ograniczajqce..., s. 292-293.

${ }^{22}$ Zob. też Ł. Żarnowiec: Wptyw statutu..., s. 314-315. Jak wskazuje M.A. Zachariasiewicz: Przepisy wymuszajace..., s. 333, wymienione w art. 30 rozporządzenia spadkowego przyczyny są tak nieostre, że trudno traktować ich katalog inaczej, jak odwołanie się do idei ochrony porządku publicznego.

${ }^{23}$ Zob. A. Machnikowska, w: Unijne rozporzadzenie..., s. 235. 
na prawo właściwe dla dziedziczenia. Powinno to wynikać z wyraźnego brzmienia tych przepisów lub zastosowania innych metod wykładni niż językowa ${ }^{24}$.

Odnosząc powyższe uwagi do ustanowienia zarządu sukcesyjnego i jego wykonywania, zaczaćc należy od tego, że przepisy ustawy nie wprowadzają ograniczeń w dziedziczeniu przedsiębiorstwa oraz nie wpływaja w jakikolwiek sposób na to dziedziczenie. Ustawa nie ingeruje w tym zakresie w działanie statutu spadkowego. Dziedziczenie przedsiębiorstwa, które prowadził w Polsce zmarły przedsiębiorca, odbywa się wyłącznie na podstawie przepisów prawa właściwego dla dziedziczenia (statutu spadkowego) ustalonego na podstawie rozporządzenia spadkowego. Natomiast nie powinno ulegać watpliwości, że cele ustawy są zgodne z celami, o których mowa w art. 30 rozporządzenia. Jej wprowadzenie motywowano utrzymaniem przedsiębiorstwa w całości i kontynuowaniem jego działalności, pomimo śmierci przedsiębiorcy, który je prowadził. Dzięki temu przedsiębiorstwo dalej może przynosić dochody rodzinie zmarłego, stanowić miejsce zatrudnienia pracowników, odprowadzać daniny publiczne itd. ${ }^{25}$

Istotne jest również, że z przepisów ustawy wprost nie wynika, że znajduje ona zastosowanie niezależnie od prawa właściwego dla dziedziczenia $^{26}$. Zresztą samo ustanowienie zarządu sukcesyjnego jest fakultatywne. Przepisy dotyczące zarządu sukcesyjnego nie nakładają obowiąku powołania zarządcy sukcesyjnego w przypadku, gdy w skład majątku spadkodawcy wchodzi przedsiębiorstwo. Nie maja one w tym zakresie charakteru imperatywnego. Powołanie zarządcy sukcesyjnego po śmierci przedsiębiorcy zależy wyłącznie od woli jego następców prawnych (właścicieli przedsiębiorstwa w spadku). Ścisła wykładnia art. 30 rozporzadzenia spadkowego (z uwagi na wyjątkowy charakter) nie pozwala na rozciaganie jego stosowania na regulacje o charakterze względnym.

$\mathrm{W}$ efekcie stwierdzić należy, że art. 30 rozporządzenia spadkowego nie uzasadnia stosowania ustawy i nie daje podstaw do ustanowienia uregulowanego $\mathrm{w}$ niej zarządu sukcesyjnego w przypadku, gdy statutem spadkowym nie jest prawo polskie ${ }^{27}$. Zarząd spadkiem jest objęty

${ }^{24}$ Zob. M. Mataczyński: Przepisy ograniczajace..., s. 293-294.

${ }_{25}$ Zob. J. Bieluk: Ustawa o zarzqdzie..., s. 2 i n.

${ }^{26}$ Inaczej M. Pazdan: Zarzqd sukcesyjny..., s. 73, a za nim Ł. Żarnowiec: Wptyw przepisów..., s. 53 i n., którzy z art. 1 ustawy wywodzą obowiązek jej stosowania niezależnie od tego, czy statutem spadkowym jest prawo polskie, czy też prawo innego państwa.

${ }^{27}$ Inny pogląd prezentują M. Pazdan: Zarzad sukcesyjny..., s. 73-74 i Ł. Żarnowiec: Wpływ przepisów..., s. 54 i n. Ich zdaniem, uzasadnienia dla stosowania przepisów ustawy dostarcza także art. 30 rozporządzenia spadkowego. Uważają oni, że oddziaływanie ustawy na zarząd przedsiębiorstwem po śmierci przedsiębiorcy oznacza wpływ 
domena statutu spadkowego, co wynika z art. 23 lit. f rozporządzenia spadkowego. Zarząd sukcesyjny uregulowany ustawa ani nie ogranicza dziedziczenia przedsiębiorstwa, ani nie wpływa na dziedziczenie przedsiębiorstwa w rozumieniu rozporządzenia spadkowego. Nie zmienia bowiem zasad przejścia przedsiębiorstwa na skutek śmierci przedsiębiorcy na jego następców prawnych („właścicieli przedsiębiorstwa w spadku” w rozumieniu ustawy). Dotyczy jedynie zarządzania przedsiębiorstwem, które w wyniku dziedziczenia przeszło na następców prawnych zmarłego przedsiębiorcy na podstawie przepisów statutu spadkowego.

Ponadto należy zwrócić uwagę na to, jakie konsekwencje związane $\mathrm{z}$ zarządem przedsiębiorstwem pojawiłyby się $\mathrm{w}$ razie stosowania art. 30 rozporządzenia spadkowego do przedsiębiorstw objętych zarzadem sukcesyjnym w przypadku, gdy statutem spadkowym byłoby prawo obce. Przede wszystkim do czasu upływu terminu do ustanowienia zarządu sukcesyjnego nie byłoby wiadomo, któremu prawu podlega zarząd przedsiębiorstwem. Zależałoby to bowiem od tego, czy po śmierci przedsiębiorcy dojdzie do ustanowienia zarządu sukcesyjnego ${ }^{28}$. Poza tym zarząd sukcesyjny i czynności dokonywane przez zarządcę sukcesyjnego nie obejmą wówczas przedmiotów będących składnikami przedsiębiorstwa położonymi w innym państwie UE niż Polska (a przynajmniej istnieje znaczne ryzyko ich nieuznawania) z uwagi na poddanie ich innemu statutowi niż statut spadkowy.

Przyjęta powyżej teza o dopuszczalności stosowania ustawy jedynie w przypadku właściwości polskiego prawa dla spraw spadkowych po zmarłym przedsiębiorcy wymaga jeszcze kilku uwag szczegółowych.

Po pierwsze, warto przypomnieć, że pomimo ostatniego miejsca zwykłego pobytu zmarłego przedsiębiorcy poza granicami Polski, fakt prowadzenia przez niego przedsiębiorstwa w Polsce może stanowić okoliczność, o której mowa w art. 21 ust. 2 rozporządzenia spadkowego, i przemawiać za właściwościa polskiego prawa do oceny spraw spadkowych po zmarłym przedsiębiorcy.

Po drugie, niezależnie od powiązań przedsiębiorcy (miejsce zwykłego pobytu, obywatelstwo, wybór statutu spadkowego), nie powinno się o dopuszczalności ustanowienia zarządu sukcesyjnego przesądzać jeszcze za życia przedsiębiorcy. Oznacza to, że niezależnie od tych powiązań każdy przedsiębiorca ujawniony w CEIDG może za życia powołać zarządcę sukcesyjnego. Jednak o tym, czy doszło do skutecznego powołania zarządcy

na jego dziedziczenie, co jednak trudno pogodzić z definicją dziedziczenia zamieszczona w rozporządzeniu (art. 3 ust. 1 lit. a) oraz wyjątkowym charakterem art. 30 rozporzadzenia spadkowego.

${ }^{28}$ W tym kontekście nabierają też znaczenia zamieszczone w ustawie przepisy o tzw. czynnościach zachowawczych, o których mowa w pkt 5 niniejszego artykułu. 
sukcesyjnego, przesądzić można dopiero po śmierci przedsiębiorcy, gdy będzie znany statut spadkowy. Zatem dopóki nie okaże się, że statutem spadkowym jest obce prawo, które nie dopuszcza zarządu sukcesyjnego, dopóty nie należy kwestionować kompetencji zarządcy sukcesyjnego do podejmowania działań związanych z zarządem przedsiębiorstwem zmarłego. Natomiast w przypadku powoływania zarzadcy sukcesyjnego po śmierci przedsiębiorcy należy brać pod uwagę prawo właściwe dla spraw spadkowych i na jego podstawie przesązać o dopuszczalności ustanowienia zarządu sukcesyjnego.

Po trzecie, w przypadku przedsiębiorcy, którego miejsce zwykłego pobytu znajduje się poza granicami Polski, powołanie zarządcy sukcesyjnego za życia przedsiębiorcy można powiązać z wyborem polskiego prawa jako statutu spadkowego ${ }^{29}$, o ile przedsiębiorca jest obywatelem polskim $\mathrm{w}$ chwili dokonywania wyboru prawa (ewentualnie będzie nim w chwili śmierci). Wówczas powołanie zarządcy sukcesyjnego stanie się skuteczne z chwilą śmierci przedsiębiorcy.

Po czwarte, pojawia się pytanie o dopuszczalność poddania obcemu prawu czynności powołania zarządcy sukcesyjnego w przypadku, gdy statutem spadkowym jest prawo polskie. Jest to czynność prawna mortis causa, jeśli powołania dokonuje przedsiębiorca. Nie jest ona jednak rozrzadzeniem według rozporządzenia spadkowego. Zgodnie z art. 3 ust. 1 lit. d rozporządzenia spadkowego, „rozrządzenie na wypadek śmierci” oznacza testament, testament wspólny lub umowę dotycząca spadku ${ }^{30}$. Nie stosuje się zatem do powołania zarządcy sukcesyjnego art. $24-27$ rozporządzenia spadkowego, regulujących właściwość prawa w zakresie dopuszczalności, ważności materialnej i formalnej rozrządzeń na wypadek śmierci ${ }^{31}$.

W uwadze 42 preambuły rozporządzenia spadkowego podano, że prawo ustalone jako prawo właściwe dla dziedziczenia powinno regulować dziedziczenie od chwili otwarcia spadku do chwili przeniesienia własności składników majątku spadkowego na beneficjentów ustalonych na mocy tego prawa. Powinno ono również regulować kwestie zwiąane $\mathrm{z}$ zarządzaniem spadkiem. $\mathrm{Z}$ art. 23 ust. 1 rozporządzenia spadkowego

29 Skuteczność wyboru prawa uzależniona jest jednak od zachowania formy wymaganej dla rozrządzenia na wypadek śmierci (art. 22 ust. 2 rozporządzenia spadkowego).

${ }^{30}$ Według rozporządzenia spadkowego, „umowa dotycząca spadku” oznacza umowę, w tym umowę wynikająca z testamentów wzajemnych, która odpłatnie lub nieodpłatnie tworzy, zmienia lub pozbawia praw do przyszłego spadku, lub przyszłych spadków po co najmniej jednej osobie będącej stroną umowy. Szerzej zob. J. Pazdan: Umowy dotyczace spadku w rozporzqdzeniu spadkowym Unii Europejskiej. Warszawa 2018, s. 173 i n.

${ }^{31}$ W Polsce i innych państwach UE będących stroną Konwencji haskiej o prawie właściwym dla formy rozrządzeń testamentowych z dnia 5 października 1961 r. (Dz.U. 1969, nr 34, poz. 284) art. 27 rozporządzenia spadkowego znajduje zastosowanie jedynie dla ustalenia prawa właściwego dla formy (innej niż ustna) umów dotyczących spadku. 
wywieść można domniemanie właściwości statutu spadkowego dla ogółu spraw dotyczących spadku. Odstępstwa od tego domniemania wynikać moga jedynie $\mathrm{z}$ samego rozporządzenia spadkowego ${ }^{32}$. Takie odstępstwo dla powołania zarządcy sukcesyjnego, jak ustalono powyżej, nie wynika $\mathrm{z}$ art. 30 rozporządzenia spadkowego. Nie wynika też ono z art. 29 rozporządzenia, który dotyczy zarządców ustanawianych obowiązkowo przez sądy.

Ustanowienie zarządu sukcesyjnego (w tym powołanie zarządcy sukcesyjnego) podlega zatem statutowi spadkowemu niezależnie od tego, czy jest dokonywane przed, czy po śmierci przedsiębiorcy. Rozporządzenie spadkowe nie przewiduje w tym zakresie możliwości wyboru innego prawa. Forma i treść oraz skuteczność czynności prawnej powołującej zarządcę sukcesyjnego podlegają statutowi spadkowemu. Jedynie ocena zdolności osób powołujących zarządcę sukcesyjnego oraz osób, których zgoda jest wymagana dla skuteczności tej czynności prawnej, odbywa się według statutu personalnego tych osób ustalanego na ogólnych zasadach. Zgodnie bowiem $\mathrm{z}$ art. 1 ust. 2 pkt b rozporządzenia spadkowego, z zakresu jego zastosowania wyłączono zdolność prawną i zdolność do czynności prawnych osób fizycznych ${ }^{33}$. Przesądzenie o wymaganej dla zarządcy sukcesyjnego pełnej zdolności do czynności prawnych następuje zgodnie ze statutem personalnym kandydata na zarządcę ustalonym na zasadach ogólnych określonych w p.p.m. $2011^{34}$. Powyższe odnosi się także do zmiany i odwołania zarządcy sukcesyjnego.

\section{Prawo właściwe dla czynności prawnych dokonywanych przez zarządlcę sukcesyjnego}

Legitymacja zarządcy sukcesyjnego do dokonywania czynności prawnych wynika ze skutecznego jego powołania (zob. pkt 3). Skuteczność powołania zarządcy sukcesyjnego oparta na przepisach statutu spadkowego nie zawsze jednak pozwoli mu na wykonywanie praw o charakterze publicznoprawnym. Potwierdza to także art. 1 ust. $1 \mathrm{zd}$. 2 rozporządzenia spadkowego, który wskazuje, że rozporządzenia nie stosuje się do spraw podatkowych, celnych ani administracyjnych. W związku z tym legitymacji tej należy poszukiwać $\mathrm{w}$ odpowiednich przepisach prawa

${ }^{32}$ Zob. m.in. jego art. 1 ust. 2.

${ }^{33} \mathrm{Z}$ zastrzeżeniem art. 23 ust. 2 lit. c oraz art. 26 rozporządzenia spadkowego.

${ }^{34}$ Zob. art. 11 p.p.m. 2011 oraz M. Pazdan: Zarzad sukcesyjny..., s. 76. 
publicznego. W przypadku zastosowania prawa polskiego znajdują się one w przepisach ustawy ${ }^{35}$. Natomiast realizacja przez powołanego na podstawie prawa polskiego zarządcę sukcesyjnego praw wynikających z norm obcego prawa publicznego może napotkać na przeszkody, których powodem będzie nieznajomość tej instytucji w tym obcym prawie ${ }^{36}$.

Zakres kompetencji zarządcy w sprawach objętych zakresem działania statutu spadkowego określa sam statut spadkowy. Dotyczy to w szczególności spraw wymienionych $\mathrm{w}$ art. 23 rozporządzenia spadkowego. Skuteczność czynności dokonanej przez zarządcę sukcesyjnego zależeć może jednak także od wymagań wynikających ze statutu rzeczowego (np.: wpis do rejestru, wydanie przedmiotu umowy, zgoda organu władzy publicznej, uwzględnienie pierwokupu o charakterze prawnorzeczowym ${ }^{37}$ ).

Przesłanki ważności czynności prawnych dokonywanych przez zarządcę sukcesyjnego podlegają co do zasady prawu właściwemu dla danej czynności prawnej ustalanemu na ogólnych zasadach. Prawo właściwe dla formy tych czynności prawnych ustalać należy na podstawie art. 11 rozporządzenia Rzym I ${ }^{38}$ lub na podstawie art. 25 p.p.m. $2011^{39}$.

35 Zob. art. 36 i n. ustawy.

${ }^{36}$ Poza ramy niniejszego opracowania wykracza kwestia dopuszczalności umieszczania w europejskim poświadczeniu spadkowym informacji na temat powołania zarządcy sukcesyjnego. Zgodnie z art. 68 pkt o rozporządzenia spadkowego, poświadczenie zawiera informacje dotyczące uprawnienia wykonawcy testamentu lub zarządcy spadku oraz ograniczeń ich uprawnień (zob. także art. 63 rozporządzenia spadkowego). Nie jest jednak jasne, czy chodzi tu o każdego zarządcę spadku lub jego składnika, czy jedynie o zarządcę powołanego na podstawie art. 29 rozporządzenia spadkowego. Zob. też M. Schauer: Europäisches Nachlasszeugnis. In: Europäische Erbrechtsverordnung. Hrsg. M. Schauer, E. Scheuba..., s. 84 i n.; C.F. Nordmeier, in: Nomoskommentar. Bd. 6. Rom-Verordnungen. Hrsg. R. Hüstege, H.P. Mansel..., s. 1078; A. Köhler, in: Internationales Erbrecht. Hrsg. W. Gierl, A. Köhler, L. KroiB, H. Wilsch..., s. 145.

${ }^{37}$ Zob. J. Górecki: Pierwokup $w$ prawie prywatnym międzynarodowym. W: Rozprawy z prawa prywatnego. Ksiega jubileuszowa dedykowana Profesorowi Wojciechowi Popiotkowi. Red. M. Pazdan, M. Jagielska, E. Rott-Pietrzyk, M. Szpunar. Warszawa 2017, s. 61.

${ }^{38}$ Rozporządzenie Parlamentu Europejskiego i Rady (WE) nr 593/2008 w sprawie prawa właściwego dla zobowiązań umownych (Rzym I). Dz.Urz. UE L nr 177, s. 6.

39 Szerzej zob. J. Pazdan, w: Prawo prywatne międzynarodowe. Komentarz. Red. M. Pazdan..., s. 283 i n. oraz J. Górecki, w: Prawo prywatne międzynarodowe. Komentarz. Red. M. Pazdan..., s. 729 i n. 


\section{Prawo właściwe dla ezynności zachowawezych dokonywanych przed powołaniem zarządcy sukcesyjnego}

Odrębnych uwag wymaga dokonywanie tzw. czynności zachowawczych po śmierci przedsiębiorcy, a przed powołaniem zarządcy sukcesyjnego. Zgodnie z art. 13 ustawy, w okresie od chwili śmierci przedsiębiorcy do dnia ustanowienia zarządu sukcesyjnego, a jeżeli zarząd sukcesyjny nie został ustanowiony - do dnia wygaśnięcia uprawnienia do powołania zarządcy sukcesyjnego, osoba, o której mowa w art. 14 ustawy, może dokonywać czynności koniecznych do zachowania majątku lub możliwości prowadzenia przedsiębiorstwa w spadku, a także czynności zwykłego zarządu w zakresie przedmiotu działalności gospodarczej wykonywanej przez przedsiębiorcę przed jego śmiercią, jeżeli ciagłość tej działalności jest konieczna do zachowania możliwości jej kontynuacji lub uniknięcia poważnej szkody.

Osobami uprawnionymi do dokonywania wymienionych powyżej czynności sa: małżonek przedsiębiorcy, któremu przysługuje udział w przedsiębiorstwie w spadku, lub spadkobierca ustawowy przedsiębiorcy, albo spadkobierca testamentowy przedsiębiorcy, albo zapisobierca windykacyjny, któremu zgodnie z ogłoszonym testamentem przysługuje udział $\mathrm{w}$ przedsiębiorstwie $\mathrm{w}$ spadku.

Po uprawomocnieniu się postanowienia o stwierdzeniu nabycia spad$\mathrm{ku}$, zarejestrowaniu aktu poświadczenia dziedziczenia albo wydaniu europejskiego poświadczenia dziedziczenia wskazanych czynności dokonywać może wyłącznie właściciel przedsiębiorstwa w spadku.

Osoby dokonujące omawianych czynności działają w imieniu własnym, ale na rachunek właściciela przedsiębiorstwa w spadku (art. 15 ustawy).

W związku z powyżej przywołanymi przepisami ustawy pojawia się pytanie, czy znajduja one zastosowanie jedynie w przypadku, gdy statutem spadkowym na podstawie rozporządzenia spadkowego okaże się prawo polskie, czy też można z nich korzystać także wówczas, gdy właściwe dla dziedziczenia po zmarłym przedsiębiorcy jest prawo obce. Odpowiedź na to pytanie powinna być podobna, jak w przypadku powołania zarządcy sukcesyjnego i wykonywania przez niego czynności związanych $\mathrm{z}$ zarządem przedsiębiorstwem w spadku. Stwierdzić zatem należy, że i w tym przypadku chodzi o zarząd przedsiębiorstwem w spadku objęty zakresem zastosowania statutu spadkowego. W konsekwencji także w odniesieniu do czynności, o których mowa w art. 13 ustawy, przyjąć trzeba, że ustawa znajdzie zastosowanie jedynie w przypadku, gdy sta- 
tutem spadkowym okaże się prawo polskie. Argumentacja za takim rozwiązaniem jest analogiczna do przedstawionej powyżej w odniesieniu do powołania zarządcy sukcesyjnego. Właściwość obcego statutu spadkowego nie zostanie tu przełamana dopuszczalnością posługiwania się ustawą. W szczególności podstawą do odejścia od właściwości statutu spadkowego w omawianym zakresie nie jest art. 30 rozporządzenia spadkowego ${ }^{40}$. Przywołane powyżej przepisy ustawy nie wprowadzają bowiem ograniczeń dotyczacych dziedziczenia przedsiębiorstwa i nie wpływaja na to dziedziczenie. Odnoszą się one wyłącznie do zarządu składnikami majątku zmarłego przedsiębiorcy.

\section{Bibliografia}

Bieluk J.: Ustawa o zarzadzie sukcesyjnym przedsiębiorstwem osoby fizycznej. Komentarz. Warszawa 2019.

Blicharz R.: Zarzad sukcesyjny przedsiębiorstwem w spadku. Warszawa 2019.

Contaldi G., in: The EU Succession Regulation. A Commentary. Eds. A.L. Calvo Caravaca, A. Davi, H.-P. Mansel. Cambridge 2016.

Dadańska K.A.: O realizacji zasady jednolitości statutu spadkowego $w$ świetle rozporzadzenia $n r$ 650/2012. „Problemy Prawa Prywatnego Międzynarodowego" 2016, T. 19.

Dutta A., in: Münchener Kommentar. Bd. 10. Internationales Privatrecht I. Hrsg. J. von Hein. München 2015.

Fischer-Czermak C.: Anwendbares Recht. In: Europäische Erbrechtsverordnung. Hrsg. M. Schauer, E. Scheuba. Wien 2012.

Górecki J.: Pierwokup w prawie prywatnym międzynarodowym. W: Rozprawy $z$ prawa prywatnego. Ksiegga jubileuszowa dedykowana Profesorowi Wojciechowi Popiotkowi. Red. M. Pazdan, M. Jagielska, E. Rott-Pietrzyk, M. Szpunar. Warszawa 2017.

Górecki J., w: Prawo prywatne międzynarodowe. Komentarz. Red. M. Pazdan. Warszawa 2018.

Kapkowski R., Kaufmann M.: Charakter prawny zarzadcy sukcesyjnego na tle pokrewnych instytucji zarzadu masa spadkowa. „Rejent” 2019, nr 7.

Köhler A., in: Internationales Erbrecht. Hrsg. W. Gierl, A. Köhler, L. KroiB, H. Wilsch. Baden-Baden 2020.

Kopaczyńska-Pieczniak K.: Status prawny zarzqdcy sukcesyjnego. „Przegląd Prawa Handlowego" 2018, nr 12.

Kopystyński K.: Zarzqdca sukcesyjny jako przedsiębiorca. „Przegląd Ustawodawstwa Gospodarczego" 2019, nr 6.

${ }^{40}$ Przeciwnie M. Pazdan: Zarzad sukcesyjny..., s. 74. 
Looschelders D., in: Nomoskommentar. Bd. 6. Rom-Verordnungen. Hrsg. R. Hüstege, H.P. Mansel. Baden-Baden 2015.

Machnikowska A., w: Unijne rozporzadzenie spadkowe nr 650/2012. Komentarz. Red. M. Załucki. Warszawa 2018.

Mansel H.P., in: Staudinger BGB. Art. 43-46 EGBGB. Internationales Sachenrecht. Hrsg. D. Henrich. Berlin 2015.

Margoński M., w: „Komentarze Prawa Prywatnego”. T. 4 B: Prawo i postepowanie spadkowe. Red. K. Os ajda. Warszawa 2018.

Mataczyński M.: Przepisy ograniczajace dziedziczenie na tle art. 30 rozporzadzenia spadkowego. W: Nowe europejskie prawo spadkowe. Red. M. Pazdan, J. Górecki. Warszawa 2015.

Müller-Lukoschek J.: Die neue EU-Erbrechtsverordnung. Bonn 2013.

Nietner S.: Internationaler Entscheidungseinklang im europäischen Kollisionsrecht. Tübingen 2016.

Nordmeier C.F., in: Nomoskommentar. Bd. 6. Rom-Verordnungen. Hrsg. R. Hüstege, H.P. Mansel. Baden-Baden 2015.

Pacek P.: Wykonawca testamentu a zarzad sukcesyjny przedsiębiorstwem osoby fizycznej-wybrane zagadnienia. „Rejent” 2019, nr 6.

Pazdan J.: Umowy dotyczace spadku $w$ rozporzadzeniu spadkowym Unii Europejskiej. Warszawa 2018.

Pazdan M.: O umowach dziedziczenia zawieranych przed polskimi notariuszami. „Rejent” 1996, nr 4-5.

Pazdan M.: Prawo prywatne międzynarodowe. Warszawa 2017.

Pazdan M.: Zarzad sukcesyjny - aspekty kolizyjnoprawne. W: Prawo handlowe. Między teoriq, praktyka a orzecznictwem. Księga jubileuszowa dedykowana Profesorowi Januszowi A. Strzepce. Red. P. Pinior i in. Warszawa 2019.

Pazdan M.: Zarzadca sukcesyjny a wykonawca testamentu. W: „Ius est ars boni et aequi”. Księga pamiatkowa dedykowana Profesorowi Józefowi Frąkowiakowi. Red. A. Dańko-Roesler, M. Leśniak, M. Skory, B. Sołtys. Wrocław 2018.

Pazdan M., w: Prawo prywatne międzynarodowe. Komentarz. Red. M. Pazdan. Warszawa 2018.

Schauer M.: Europäisches Nachlasszeugnis. In: Europäische Erbrechtsverordnung. Hrsg. M. Schauer, E. Scheuba. Wien 2012.

Szczurowski T.: Zarzą sukcesyjny przedsiębiorstwem w spadku. „Przegląd Ustawodawstwa Gospodarczego" 2018, nr 11.

Twardoch P., w: Prawo prywatne międzynarodowe. Komentarz. Red. M. Pazdan. Warszawa 2018.

Wendehorst C., in: Münchener Kommentar. Bd. 11. Internationales Privatrecht II. Hrsg. J. von Hein. München 2015.

Wieczorek A.: Ustalenie prawa właściwego w świetle rozporzadzenia spadkowego nr 650/2012. „Problemy Prawa Prywatnego Międzynarodowego” 2017, T. 21. 
Zachariasiewicz M.A.: Przepisy wymuszajace swoje zastosowanie a statut spadkowy. W: Nowe europejskie prawo spadkowe. Red. M. Pazdan, J. Górecki. Warszawa 2015.

Zachariasiewicz M.A., w: Prawo prywatne międzynarodowe. Komentarz. Red. M. Pazdan. Warszawa 2018.

Żarnowiec Ł.: Wpływ przepisów wymuszajacych swoje zastosowanie na rozstrzyganie spraw spadkowych pod rzadami rozporzadzenia Parlamentu Europejskiego i Rady (UE) nr 650/2012. „Problemy Prawa Prywatnego Międzynarodowego" 2019, T. 25.

Żarnowiec Ł.: Wptyw statutu rzeczowego na rozstrzyganie spraw spadkowych - na styku statutów. Warszawa 2018. 